\title{
Nerve Injury Enhances Rat Neuronal Glutamate Transporter Expression: Identification by Differential Display PCR
}

\author{
Sumiko Kiryu, Gui Lan Yao, Naonori Morita, Hidemasa Kato, and Hiroshi Kiyama \\ Department of Neuroanatomy, Biomedical Research Center, Osaka University Medical School, Osaka 565, Japan
}

\begin{abstract}
An increase in neuronal glutamate transporter expression after nerve injury was demonstrated by means of differential display PCR (DD-PCR) coupled with in situ hybridization. DD-PCR was carried out to compare differences in expression of mRNAs between axotomized and normal hypoglossal motoneurons in the rat. The expression of several gene fragments were found to be increased following nerve injury; the full length cDNA corresponing to one fragment was cloned by subsequent rat cDNA library screening. The close homology of glutamate transporters with our rat CDNA led us to conclude that this clone corresponds to the rat neuronal glutamate transporter (rat EAAC1). We speculate that the upregulation of this glutamate uptake system may increase the resistance of these cells against neurotoxic glutamate accumulation during the process of nerve regeneration.
\end{abstract}

[Key words: nerve regeneration, hypoglossal nerve, neuronal high affinity glutamate transporter, glutamate toxicity, cell death]

Nerve regeneration is a complex process involving many metabolic and catabolic pathway. Previous reports have demonstrated that molecules such as growth factors (Heumann et al., 1987a,b; Eckenstein et al., 1991; Kobayashi et al., 1993), some peptides (Saika et al., 1991) and cytoskeltonal proteins (Tetzlaff et al., 1991; Tsui et al., 1991) are upregulated during peripheral nerve regeneration. However, the molecular events associated with axotomy are still not well understood.

Recently, we have focused our attention on several molecules that are involved in the signal transduction pathways during hypoglossal nerve regeneration (Ohno et al., 1994; Saika et al., 1994; Kiryu et al., 1995; Morita et al., 1995). These studies implicate some signal transduction pathways such as that involving Ras pathway in regeneration associated signaling pathway. By examining individual intracellular signaling molecules associated with regeneration, we hope to gain insight into the phenomena underlying of successful nerve regeneration. However, it is likely that a number of other so far unknown molecules and genes will play an important role in nerve regeneration.

\footnotetext{
Received June 9, 1995; revised Aug. 18, 1995; accepted Aug. 24, 1995.

We are grateful to Dr. M. Tohyama for encouragement, Drs. P. C. Emson and S.J. Augood for critical reading and English correction and Drs. Y. Kanai, and K. Tanaka for useful advice. This work was supported by Ciba-Geigy science foundation and Uehara memorial foundation, and Grant-in-Aid for Scientific Research from the Ministry of Education, Science and Culture Japan.

Correspondence should be addressed to Dr. Hiroshi Kiyama, Department of Neuroanatomy, Osaka University Medical School, 2-2 Yamadaoka, Suita, Osaka 565, Japan.

Copyright (C) 1995 Society for Neuroscience $0270-6474 / 95 / 157872-07 \$ 05.00 / 0$
}

Therefore, an alternative method to quickly isolate those.genes which may be involved in the nerve regeneration event, has been sought. The development of a new technique termed differential display PCR (DD-PCR) has considerably simplified the identification of genes upregulated after axotomy or lesion, replacing earlier subtractive strategies (Liang et al., 1992; Liang and Pardee, 1992). The method is based on directly comparing the mRNAs expressed in two or more cell populations, separating their reverse transcription-PCR products and comparing band patterns. We have used this method to identify a gene not previously implicated in peripheral nerve regeneration. Using this approach, we identified the rat homolog of the neuronal high affinity glutamate transporter (rabbit EAACI or human EAAT3) (Kanai and Hediger, 1992; Meister et al., 1993; Arriza et al., 1994) and showed that this glutamate transporter is upregulated in injured motoneurons. High affinity glutamate transporter have recently been defined by molecular cloning (Kanai and Hediger et al., 1992; Pines el al., 1992; Sturck et al., 1992; Arriza et al., 1994 ) and represent a new family of $\mathrm{Na}^{+}$and $\mathrm{K}^{+}$coupled electrogenic transporters, which have no significant primary structural homology to the superfamily of $\mathrm{Na}^{+}$and $\mathrm{Cl}^{-}$coupled transporters (Amara, 1993). These transporters mediate the cellular uptake of acidic and neutral amino acids from the synaptic cleft into glial cells (GLAST, GLT1) or nerve endings (EAAC1). Since glutamate is neurotoxic (Benveniste et al., 1984; McBean et al., 1985; Choi et al., 1988) as well as being the principal excitatory amino acid neurotransmitter (Fonnum et al., 1984), transporter-mediated uptake systems may serve to maintain extracellular glutamate concentrations below toxic levels (Nicholis et al., 1990; Eliasof et al., 1993). It has also been suggested that several neurodegenerative disorders are due to dysfunction of glutamate transporters (Rothstein et al., 1992). In this study, we show that rat EAAC1, cloned by DD-PCR, is associated with axotomy-induced nerve regeneration. In addition, the distribution of rat EAAC1 mRNA was demonstrated in the adult rat brain.

\section{Materials and Methods}

Animals. Seventy male Wistar rats weighing about $100 \mathrm{gm}$ were anesthetized with pentobarbital $(45 \mathrm{mg} / \mathrm{kg})$, positioned supine and their right hypoglossal nerve cut with scissors, the hypoglossal nuclei were then dissected from the operated- and normal-sides (Fig. 1A). Seventy hypoglossal nuclei (operated and normal) were collected and frozen in liquid nitrogen. For in situ hybridization, rats were sacrificed 1, 3, 5, 7, $14,21,28$, and $35 \mathrm{~d}$ afer the operation (three rats each point).

Differential display PCR (DD-PCR). DD-PCR was carried out (Fig. 1A) as previously described (Liang et al., 1992; Liang and Pardee, 1992; Bauer et al., 1993). Total RNA (approximately $70 \mu \mathrm{g}$ ) was obtained from either the operated or the normal hypoglossal nuclei $7 \mathrm{~d}$ after surgery. Total RNA (each $0.2 \mu \mathrm{g}$ ) was converted to cDNA with superscript reverse transcriptase (GIBCO/BRL) and nucleotide oligo $\mathrm{dT}_{18}$. 
A

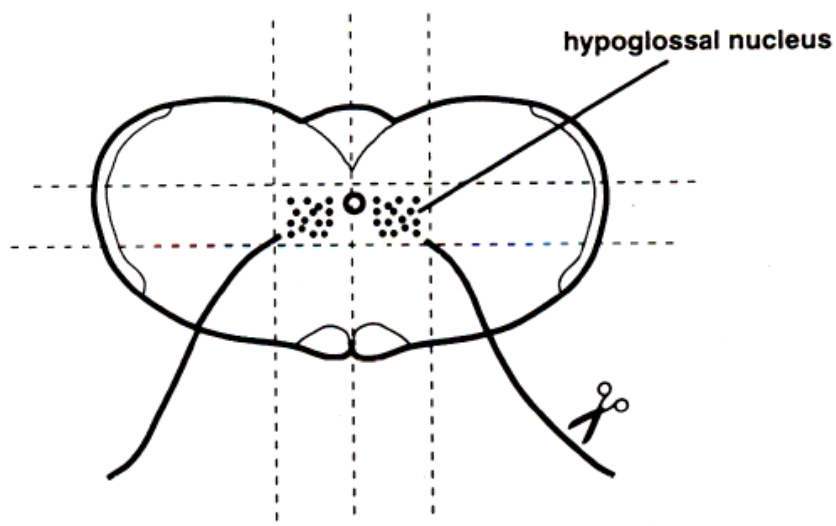

B

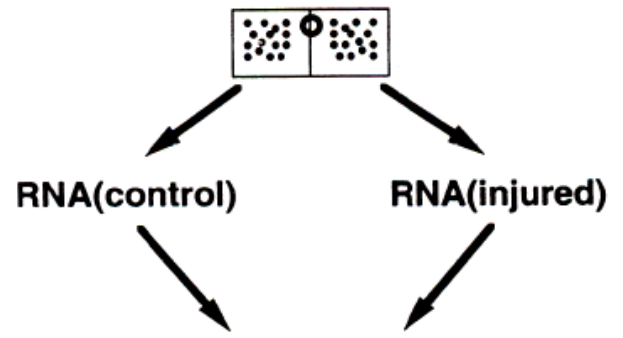

DD-PCR

Figure 1. A, Preparation of tissue for DD-PCR. Differential display comparing mRNAs from both the normal (left) and injured (right) hypoglossal nuclei; tissue was carefully dissected and total RNA was prepared from each hypoglossal nucleus. $B$ shows autoradiography of amplified ${ }^{35} \mathrm{~S}$-labeled PCR products (after electrophoresis in a 5\% polyacrylamide gel) using two arbitrary primers. The left lane corresponds to PCR products derived from the normal hypoglossal nucleus and the right lane is from the operated side. Arrowhead indicates a differentially expressed band which is located at about $200 \mathrm{bp}$ in size.

Subsequently, 1/10 volume of the each pool of cDNA was amplified by PCR in the presence of $\alpha-{ }^{35} S$ dATP (New England Nuclear-Du Pont, Natick, MA) using two arbitrary primers, 5'-AGGGGAACTGCTGGGGTCGTCCCGGTGGTC-3' and 5'-GGCCTTCATGTTAATGATGCAATTAAGGTC- $3^{\prime}$, which were selected among 87 arbitary primers by chance. The cycling parameters are as follows: denaturation at $94^{\circ} \mathrm{C}$ for $5 \mathrm{~min}, 40$ cycles with denaturation at $94^{\circ} \mathrm{C}$ for $30 \mathrm{sec}$, annealing at $42^{\circ} \mathrm{C}$ for $1 \mathrm{~min}$ and extension at $72^{\circ} \mathrm{C}$ for $1.5 \mathrm{~min}$ and an additional extention period at $72^{\circ} \mathrm{C}$ for $5 \mathrm{~min}$. Radiolabeled PCR products were analyzed by electrophoresis on a 5\% sequencing gel, and visualized by autoradiography. Differentially upregulated bands were recovered from dried denaturing polyacrylamide gels and reamplified in a 40 cycles PCR using the same primers. Reamplified cDNA products were cloned into $\mathrm{PCR}^{\mathrm{TM}} \mathrm{II}$ vectors using the TA cloning kit (Invitrogen, San Diego, CA).

In situ hybridization. Animals were decapitated 1, 2, 3, 5, 7, 14, and $21 \mathrm{~d}$ after surgery. Their brains were removed quickly and frozen in powdered dry ice; $20 \mu \mathrm{m}$ thick sections were cut on a cryostat, thawmounted onto 3-aminopropyltriethoxysilane coated slides, and stored at $-80^{\circ} \mathrm{C}$ until used. Just before use, the sections were fixed in $4 \%$ paraformaldehyde in $0.1 \mathrm{M}$ phosphate buffer (PB) for $20 \mathrm{~min}$, washed in $\mathrm{PB}$, treated with $10 \mu \mathrm{g} / \mathrm{ml}$ proteinase- $\mathrm{K}$ in $50 \mathrm{~mm}$ Tris-HCL and $5 \mathrm{~mm}$

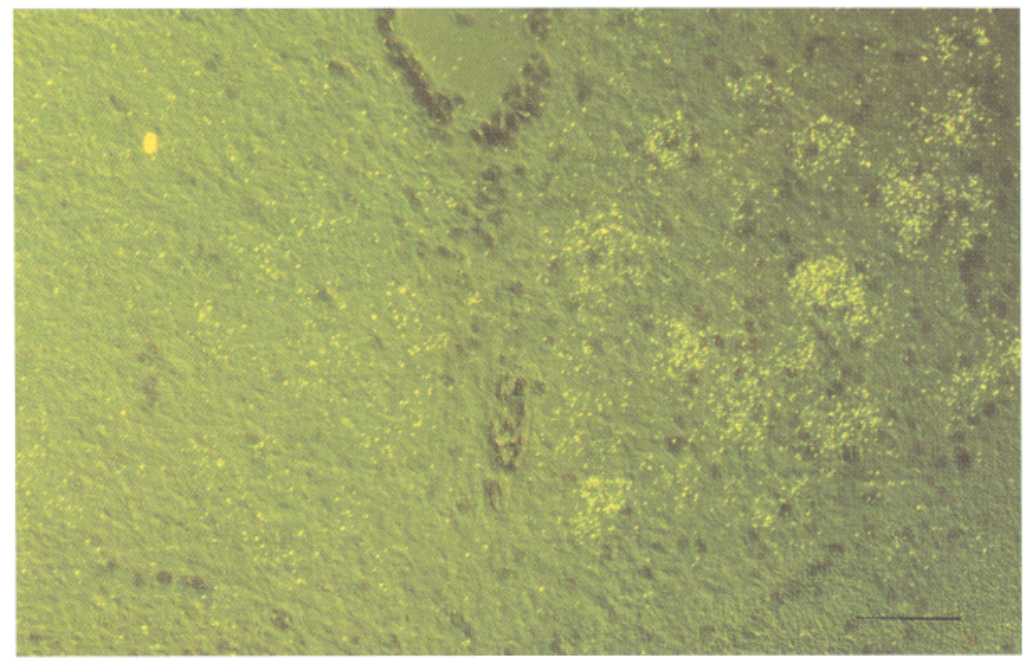

Figure 2. Histological display by in situ hybridization using the cRNA probe derived from cDNA fragment shown in Figure $1 B$ (arrowhead). The section was obtained from an animal whose unilateral hypoglossal nerve was axotomized $7 \mathrm{~d}$ before (right side is the operated side). The counterstained emulsion autoradiography is observed under semidarkfield observation. Note the accumulation of silver grain is observed only on the injured motoneurons. Scale bar, $40 \mu \mathrm{m}$. 




Figure 3. Nucleotide and deduced amino-acid sequence of the rat EAAC1. Eleven positive plaques were isolated. The location of the cDNA fragment obtained by DD-PCR relative to the original cDNA is underlined. Putative protein kinase C-dependent phosphorylation sites (S/T-X-K/R) are located at residues $87,115,121,164,247,340,466$, 500 . Potential N-linked glycosylation sites are located at $85,178,195$. Regions of serine-rich motif and the conserved seven amino acids, AAXFIAQ are underlined in bold. The nucleotide sequence data reported in this paper will appear in the DDBJ, EMBL, and GenBank nucleotide sequence databases with following accession number: D63772.

EDTA for $10 \mathrm{~min}$ and then fixed again. After washing in distilled water, sections were acetylated with $0.25 \%$ acetic anhydride in $0.1 \mathrm{M}$ triethanolamine, rinsed with $\mathrm{PB}$, dehydrated in ascending ethanol series $70 \%$, $95 \%$ and $100 \%$ ), defatted in chloroform, rinsed in ethanol and air dried. ${ }^{35}$ S-labeled RNA probes were prepared by in vitro transcription of the

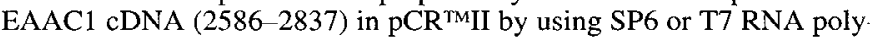
merase and $\alpha-{ }^{35}$ S-UTP (New England Nuclear-Du Pont, Natick, MA). The labeled probes $\left(5 \times 10^{6} \mathrm{cpm} / \mathrm{ml}\right)$ in hybridization buffer $(50 \%$ deionized fornamide, $0.3 \mathrm{M} \mathrm{NaCl}, 20$ пाм Tris- $\mathrm{HCl}, 5$ Inм EDTA, 10 $\mathrm{mm} \mathrm{PB}, 10 \%$ dextran sulfate, $1 \times$ Denhardt's solution, $0.2 \%$ sarcosyl,
EAAC1 rat

EAAC1 rabbit

EAAT3 human

1:MGKPTSSGC-DWRRFLRNHWLLLSTVAAVVLGIVVGVLVRGHSELSNLDKFYFAFPGEIL

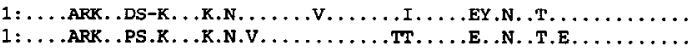

EAAC1 rat

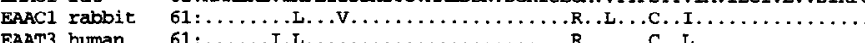

EAAC1 rat 121:VTOKVNETNRTEKTPEVSTVDAMLDLIRNMFPENLVOACFOOYKTKREEVKPASDPGGNO EAACl
EAAT3
human
$121: \ldots \ldots$.

EAAC1 rat

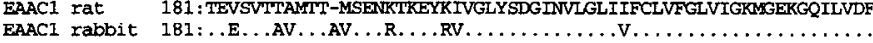

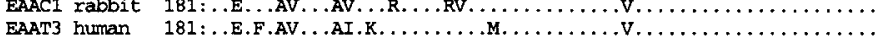

EAAC1 rat 241: FNALSDATMKIVQI IMCYMPIGILFL IAGKIIEVEDWEIFRKLCLYMATVLSGLAIHSLV

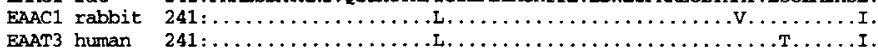

EAAC1 rat 301:VLPLIYF IVVRKNPFRFALGMAQALLTALMISSSSATLPVIFRCAEEKNHVDKRITRFVL

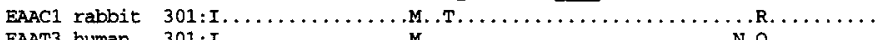

EAAT3 human $301: 1, \ldots \ldots \ldots \ldots \ldots \ldots \ldots \ldots \ldots \ldots$

EAAC1 rat 361: PVGATINMDGTALYEAVAAVE LAOVNGMDLSIGOIITISITATAASIGAAGVPOAGLVTM

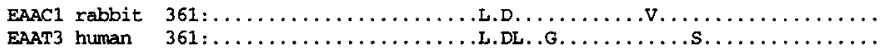

EAAC1 rat

EAAC1 rabbIT 421:VIVLSAVGLPABDVILIIAVDWLLLRFRTMUNVIGDAFGTGIVERLSKKKELEQVDVSSEV

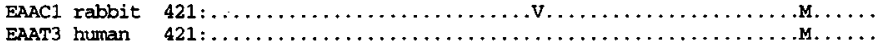

EAAC1 rat 481: NTUNPFALEPITLDNEDSDTKKSYUNGGFSVDKSDTISFTQTSQF

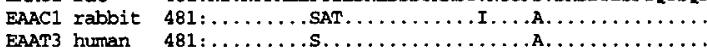

Figure 4. Alignment of neuronal high affinity glutamate transporter sequence. Regions of serine rich motif (SSSS) and conserved amino acids (AAXFIAQ) are underlined. Sequences are taken from the following references: EAACl (Kanai and Hediger, 1992), EAAl'3 (Arriza et al., 1994).

$500 \mu \mathrm{g} / \mathrm{ml}$ yeast transfer RNA, and $200 \mu \mathrm{g} / \mathrm{ml}$ salmon sperm DNA) were denatured for $2 \mathrm{~min}$ at $80^{\circ} \mathrm{C}$, quenched on ice and placed on the these sections. Hybridization was performed in a humid chamber overnight at $55^{\circ} \mathrm{C}$. Hybridized sections were rinsed briefly in $5 \times \mathrm{SSC}-1 \%$ 2 -mercaptoethanol at $55^{\circ} \mathrm{C}$, washed in $50 \%$ deionized formamide, $2 \times$ SSC and 10\% 2-mercaptoethanol (high stringency buffer) for $30 \mathrm{~min}$ at $60^{\circ} \mathrm{C}$. After rinsing the sections in RNase buffer $(0.5 \mathrm{M} \mathrm{NaCl}, 10 \mathrm{~mm}$ Tris- $\mathrm{HCl}$ and $1 \mathrm{~mm}$ EDTA), they were treated with $1 \mu \mathrm{g} / \mathrm{ml}$ RNase-A in RNase buffer for 30 min at $37^{\circ} \mathrm{C}$ and washed in RNase buffer. Sections were then incubated in buffer as described above, rinsed with 2 and $0.1 \times$ SSC for 10 min each at room temperature, dehydrated in an ascending ethanol series, and air dried. Sections were then exposed to $\mathrm{X}$-ray film for 2 weeks, whereafter they were dipped in Ilford K-5 photoemulsion (Ilford, UK) diluted 6:4 in water. Sections were then exposed for 3-4 weeks at $4^{\circ} \mathrm{C}$, developed in Kodak D19 developer, counterstained with thionin, dehydrated in a graded series of ethanol to $x y-$ lene, and coverslipped before microscopic observation.

Relative quantification of $m R N A$. The grain intensity on the $\mathrm{x}$-ray film was measured. The relative area occupied by autoradiographic grains in the hypoglossal nuclei was measured bilaterally on the $x$-ray film using a computerized image analysis system (MCID: Image Res. Inc., Ontario, Canada). In the same sections, we calculated the difference in the optical density between the right (ipsilateral side) and the left hypoglossal nuclei (contralateral side). For statistical analysis, at least eight sections from three rats were studied.

cDNA library screening. A rat brain cDNA library(Uni-ZAP XR Library, Stratagene, La Jolla, CA) was screened with a subcloned PCRderived DNA fragment to obtain a larger cDNA clone. The probe was labeled with $\alpha^{-32} \mathrm{P}$ dCTP (Amersham, UK) by multiprime DNA labeling system (Amersham, UK). Approximately $1 \times 10^{6}$ plaques were plated at a density of $1 \times 10^{4} \mathrm{pfu} / 150 \mathrm{~mm}$ dish and screened following conditions for hybridization: $1 \times 10^{6} \mathrm{cpm} / \mathrm{ml}$ in $6 \times \mathrm{SSC}, 5 \times$ Denhardt's and $0.5 \%$ SDS for hybridization at $65^{\circ} \mathrm{C}$, and washed at $65^{\circ} \mathrm{C}$ in $2 \times$ SSC and $0.5 \%$ SDS. Eleven positive plaques were obtained and purified by in vivo excision for plasmids. Both strands of these cDNA inserts were sequenced automatically by the dyeprimer cycle sequence kit using an Applied Biosystems model 373A DNA sequencer (Applied Biosystems. Inc., CA).

\section{Results}

\section{Differential display PCR}

The expression of mRNAs $7 \mathrm{~d}$ after nerve cut were analyzed using DD-PCR. We performed PCR amplifications with two 

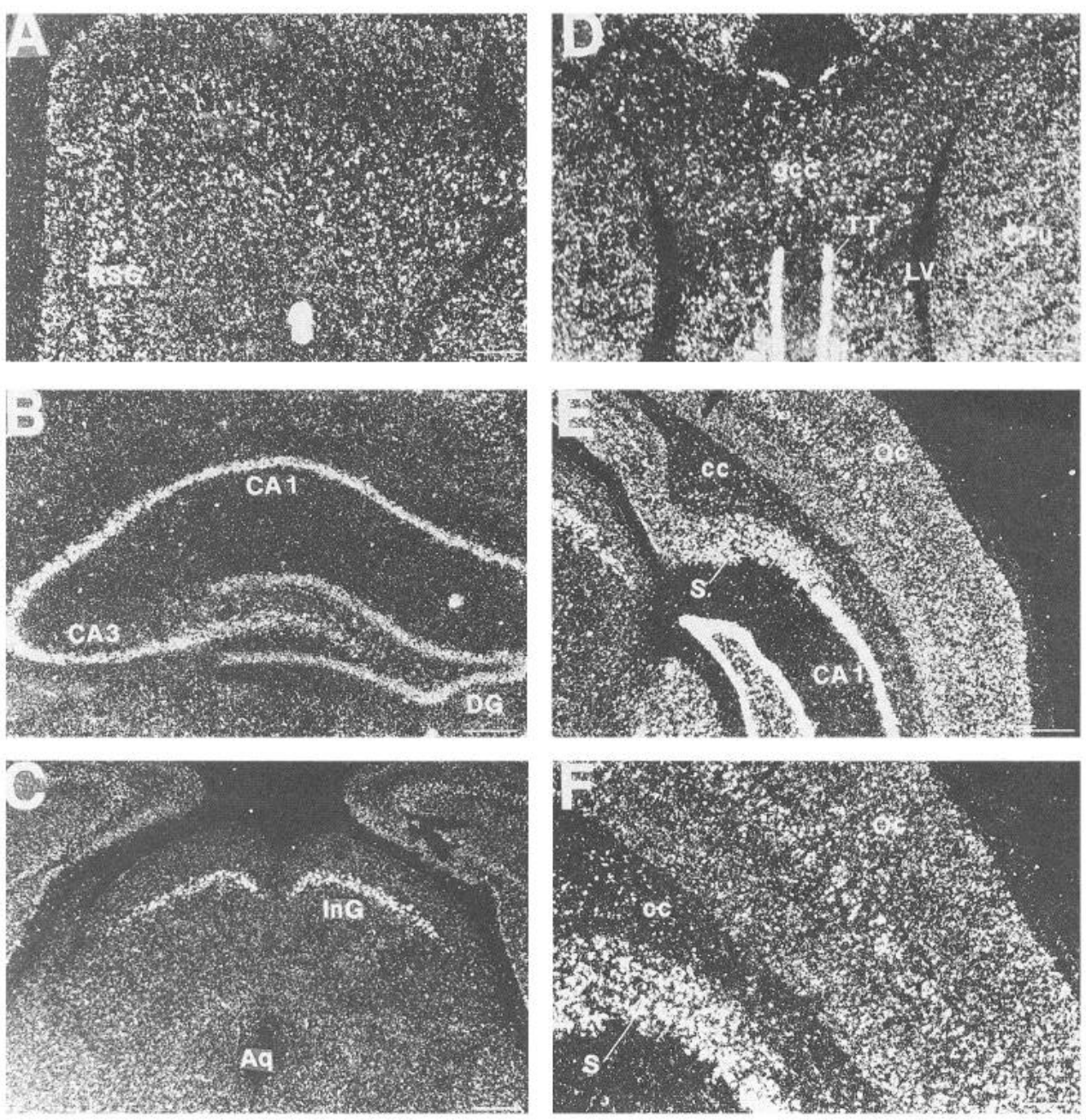

Figure 5. Expression of the rat EAAC1 mRNA in rat brain. $A-C$ show a strong expression of the rat EAAC1 mRNA in neurons of the retrosplenial granular cortex $(A)$, the hippocampus $(B)$, and the superior colliculus $(C) . D-$ $F$ indicate the rat EAAC1 mRNA expression in the corpus callosum ( $g c c$, $c c$ ) at three different levels of the brain. In addition, intense hybridization signal is also observed in various regions such as the $\mathrm{CPu}(D)$, cerebral cortex $(E, F)$ and $\mathrm{S}(E, F)$. Abbreviations: $R S G$, retrosplenial granular cortex; $C A 1$ and 3 , fields of CA 1 and 3 of Ammon's horn; $D G$, dentate gyrus; $\operatorname{In} G$, intermediate gray layer superior colliculus; $A q$, aqueduct; $g c c$, genu corpus callosum; $T T$, tenia tecta; $L V$, lateral ventricle; $C P u$, caudate putamen; $c c$, corpus callosum; $O c$, occipital cortex; $S$, subiculum. Scale bars: $A, D, E, 300 \mu \mathrm{m} ; B, 140$ $\mu \mathrm{m} ; C, 165 \mu \mathrm{m} ; F, 120 \mu \mathrm{m}$. primer combinations. The pattern of amplified cDNA fragments is indicated in Figure $1 B$. A cDNA fragment located at about $200 \mathrm{bp}$ (arrowhead) was amplified to a greater degree on the operated side. This $200 \mathrm{bp}$ band was excised and used for further analysis. In order to eliminate possible false positive signal, the observed ncrease in mRNA expression was confirmed on tissue sections by in situ hybridization. The cDNA fragment recovered from the differential display analysis was reamplified and used as a probe for in situ hybridization. This histological survey revealed a significant increase in mRNA expression in cells in the injured hypoglossal nucleus (Fig. 2).

\section{Molecular cloning}

We screened a rat brain cDNA library to isolate a full length cDNA clone using radio-labeled cDNA fragments recovered by DD-PCR. Among the 11 positive plaques identified, 4 plaques contained a full length clone. Searching of the nucleotide database, DDBJ, revealed that this clone had high homology with a neuronal high affinity glutamate transporter isolated from rabbit small intestine EAAC1 (Kanai et al., 1992) and human brain EAAT3 (Arriza et al., 1994). The nucleotide sequence of this clone is shown in Figure 3. cDNA sequencing revealed an open reading frame from nucleotides 121-1689 which encoded a 523 amino acid protein. Protein homology revealed a $89 \%$ sequence identity with rabbit EAAC1 and a $90 \%$ identity with the human EAAT3. Alignment of the amino acid sequences illustrates the extensive conservation (Fig. 4). Thus, we conclude that this clone is a rat homolog of the rabbit EAAC1 and human EAAT3 clones.

\section{Distribution of rat EAAC1 in the brain}

To identify if the cloned glutamate transporter is of the neuronal type or not, in situ hybridization histochemistry was performed on fresh frozen rat brain sections. The expression of the rat clone EAAC1 was observed primarily in most neurons with various levels of expression. In particular, neurons in the cerebral cortex, hippocampus, and restricted layers of the superior colliculus (the inter mediate gray layer) expressed substantial amounts of the rat EAAC1 mRNA (Fig. 5). The distribution of rat EAAC1 mRNA in the brain was similar to that of EAAC1 imunoreactivity (Rothstein et al., 1994). In addition, flat glial cells in the corpus callosum, presumed to be oligodendrocyte, also expressed mRNA for the high affinity glutamate transporter (Fig. $5 D-F)$.

\section{Expression profile of the rat EAACI during nerve regeneration}

We carried out in situ hybridization to evaluate changes in expression of the rat EAAC1 clone over time during nerve regeneration (Fig. 6, 7). A slight increase in the rat EAAC1 hybridization signal was detected initially in the ipsilateral hypoglossal nucleus $1 \mathrm{~d}$ after the nerve cut, however the intensity of the hybridization signal markedly increased to peak levels during 

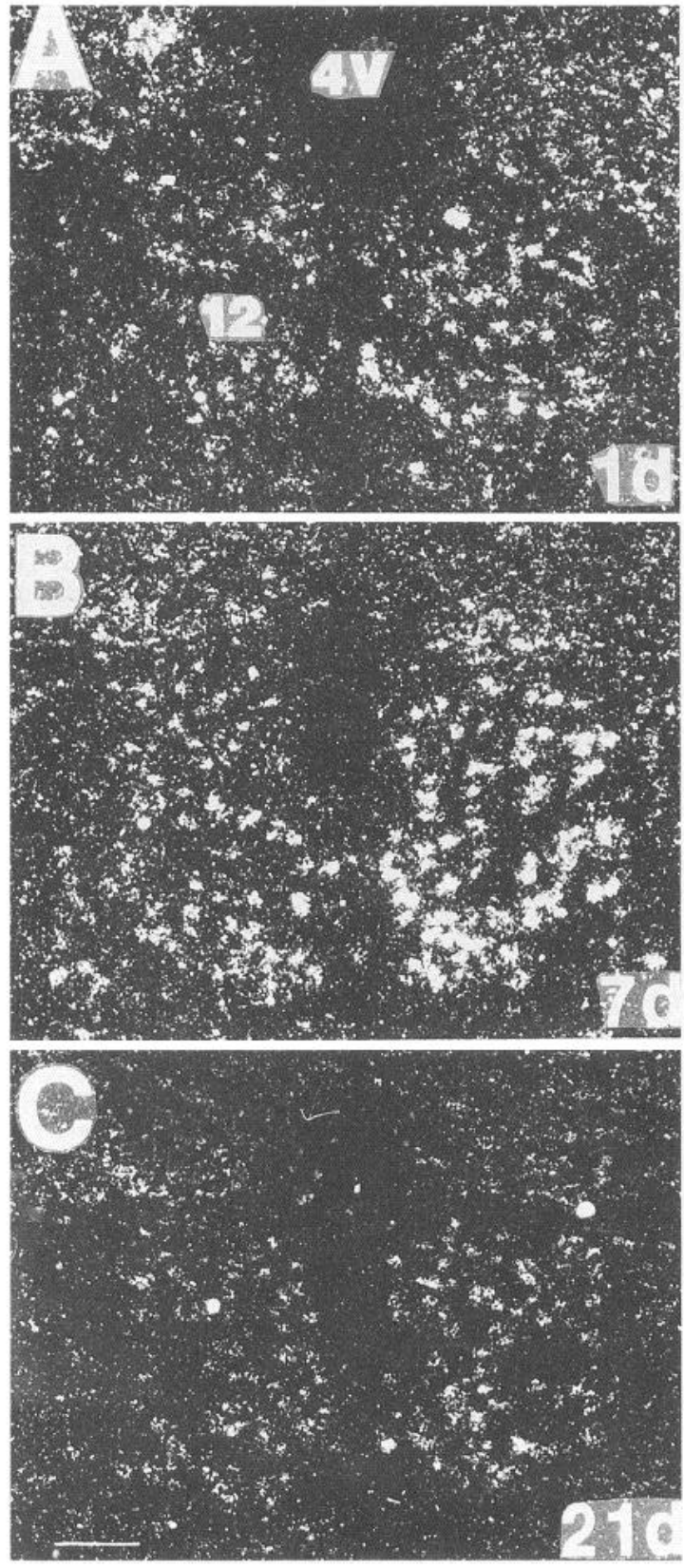

Figure 6. Expression of the rat EAAC1 mRNA in the hypoglossal nucleus $1 \mathrm{~d}(A), 7 \mathrm{~d}(B)$, and $21 \mathrm{~d}(C)$ after unilateral hypoglossal nerve transection (right side). $4 V$, Fourth ventricle; 12 , hypoglossal nucleus. Scale bar, $75 \mu \mathrm{m}$.

the following $3 \mathrm{~d}$ (Fig. 7) and persisted at this level for about 7 d. Thereafter, the hybridization signal gradually decreased to control level over the following 3 weeks.

\section{Discussion}

In the present study, the technique of DD-PCR was used to identify genes associated with hypoglossal nerve regeneration. In particular, one candidate cDNA fragment (200 bp) was isolated and sequenced (Fig. 1). Although this method can be used successfully to isolate candidate cDNAs, it has some technical disadvantages over traditional differential expression cloning methods; one disadvantage is the high incidence of false positives (Nishio et al., 1994). To eliminate these false positives, in

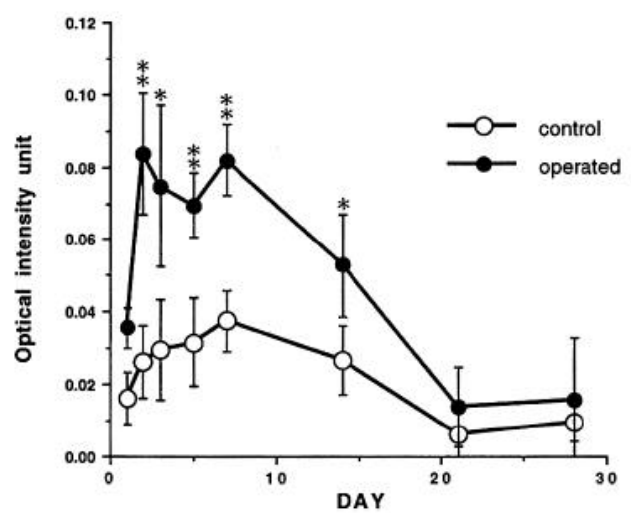

Figure 7. Expression profile of rat EAACl mRNA in both resection side (solid circle) and control side (open circle). Each point shows the average intensity of the positive signals and its SD. Asterisks denote statistically significant differences (Student's $t$ test) from control: ${ }^{*}, p$ $<0.05 ; * *, p<0.01$.

situ hybridization histochemistry was used as a secondary screening method. This histological approach, in situ differential display, allows false positive clones to be effectively eliminated. About $60-70 \%$ of bands initially displayed on the gel were false positives when assessed using in situ hybridization.

Subsequent screening of a cDNA library showed that the clone isolated here corresponded to the rat homolog of a neuronal high affinity glutamate transporter. Comparing the amino acid sequences of the rat clone with the rabbit and human sequences revealed that the rat homolog also conserves an AAXFIAQ structural motif and serine-rich sequences (SSSS) (Figs. 3, 4). In situ hybridization further suggested that the present clone was expressed primarily in neurons although some glial expression was observed. Taking all this data into consideration, we suggest that the clone derived by DD-PCR is the rat homolog of the rabbit EAAC1/human EAAT3 sequences. Further, expression of this neuronal type of glutamate transporter is upregulated following peripheral nerve injury.

Glutamate is the major excitatory neurotransmitter in the nervous system as well as a neurotoxin. Under normal conditions, glutamate signal transmission is terminated by the rapid uptake of glutamate into presynaptic nerve terminals and into surrounding glia (Nicholls and Attwell, 1990). It is conceivable that abnormal glutamate uptake may be closely related to an increase in extracellular glutamate concentrations as observed in certain neurodegenerative diseases (Drejer et al., 1985; Silverstein et al., 1986; Ikeda et al., 1989). However, the kinetics of the glutamate transport system in such conditions is still controversial. Several studies have demonstrated that an excess of glutamate in the synaptic cleft results from a reduction in the density of glutamate transporter in spinal cord and brain tissues from patients with amyotrophic lateral sclerosis (ALS) (Rothstein et al., 1992). Further, in ischemia or anoxia, rundown of $\mathrm{Na}^{+}, \mathrm{K}^{+}$and voltage gradients is expected to initiate reversal of the $\mathrm{Na}^{+}$-dependent and electrogenic glutamate uptake carrier, releasing excess glutamate into the extracellular space (Szatkowski et al., 1990; Lysko et al., 1994a,b). This abnormal $\mathrm{Ca}^{2+}$-independent nonvesicular release of glutamate results in a reduction of glutamate clearance at the synaptic cleft, activation of NMDA receptors and subsequent $\mathrm{Ca}^{2+}$ influx leading to neural death (Andreeva et al., 1991; Waxman et al., 1991). After traumatic brain injury, an increase in extracellular concentrations of glutamate is also 
observed (Nilsson et al., 1990, 1994). In addition, Takata (1993) has reported that following hypoglossal nerve axotomy the inhibitory input to the hypoglossal motoneurons decreased whereas the excitatory component remained. This may also contribute the increase of extracellular gutamate. Thus, the present study indicates that axotomized motoneurons produce substantial amounts of glutamate transporter, possibly in an attempt to remove extracellular glutamate and reduce glutamate concentrations to within the physiological range. Thus, at least in the present case the neuronal glutamate transporter isolated may be functioning to reduce local glutamate concentrations and thus increase neuronal survival. Enhanced expression of the rat EAAC1 was not detected immediately after the nerve injury; the maximum expression was seen from day 4 to day 11 , and there after the expression of rat EAAC.1 returned to control levels during the following 3 weeks (Fig. 7). This period corresponds to only $1 / 2$ the period required for complete reinnervation of injured axons (Kobayashi et al., 1994). During this earlier phase of nerve regeneration, injured motoneurons loose their synaptic contacts, suggesting that the newly synthesized glutamate transporter may be functioning not to terminate glutamate signaling, but for some other function. It is possible that these newly synthesized glutamate transporters may function to reduce glutamate levels and therefore protect damaged motor neurons from glutamate mediated cell death. Alternatively it may be that the cells require increased glutamate for protein synthesis.

The family of glutamate transporters is generally divided into two subsets, neuronal (e.g., EAAC1) (Kanai and Hediger, 1992; Arriza ct al., 1994; Kanai et al., 1994) and glial (e.g., GLAST, GLT1) (Pines et al., 1992; Storck et al., 1992; Kanner, 1993). Analysis of the expression pattern of rat EAACl mRNA in brain, by in situ hybridization histochemistry indicates that the rat EAACl is localized widely in neurons as described previously (Kanai and Hediger, 1992; Rothstein et al., 1994). However, the intensity of the rat EAAC1 mRNA signal varied among different populations of neurons. Some neurons express little or almost no EAAC1 mRNA. Since many populations of neurons use glutamate for neurotransmission, there may be additional subtypes of neuronal glutamate transporters which are enriched in regions where the rat EAAC1 is not widely expressed. The neuronal glutamate transporters EAAC1 and EAAT3 have been shown to be expressed in neurons; however, we report here that mRNA for the cloned rat EAACl was additionally expressed in flat-shaped cells in the white matter, for example the corpus cullosum (Fig. 5). Thus, although the rat EAACl is a major neuronal glutamate transporter, it is also expressed in some glial components such as the oligodendrocytes.

\section{References}

AInara SG (1993) Neurotransmitter transporters: recent progress. Annu Rev Neurosci 16:73-93.

Andreeva N, Khodorov B, Stelmashook E, Cragoe E, Victorov I (1991) Inhibition of $\mathrm{Na}^{+} / \mathrm{Ca}^{2+}$ exchange enhances delayed neuronal death elicited by glutamate in cerebellar granule cell cultures. Brain Res 548:322-325.

Arriza JL, Fairman WA, Wadiche JI, Murdoch GH, Kavanaugh MP, Amara SG (1994) Functional comparisons of three glutamate transporter subtypes cloned from human motor cortex. J Neurosei 14 5559-5569.

Bauer D, Müller H, Reich J, Riedel H, Ahrenkiel V, Warthoe P, Strauss M (1993) Identification of differentially expressed mRN $\Lambda$ species by an improved display technique (DDRT-PCR). Nucleic Acids Res 21:4272-4280.

Benveniste H, Drejer J, Schousboe A, Diemer NH (1984) Elevation of the extracellular concentrations of glutamate and aspartate in rat hip- pocampus during transient cerebral ischemia monitored by intracerebral microdialysis. J Neurochem 43:1369-1374.

Choi DW (1988) Glutamate neurotoxicity and disease of the nervous system. Neuron 1:623-634.

Drejer J, Benveniste H, Diemer NH, Schousboe A (1985) Cellular origin of ischemia-induced glutamate release from brain tissue in vivo and in vitro. $J$ Neurochem 45:145-151.

Eckenstein FP, Shipley GD, Nishi R (1991) Acidic and basic fibroblast growth factors in the nervous system: distribution and differential alternation of levels after injury of central versus peripheral nerve. $J$ Neurosci 11:412-419.

Eliasof S, Werblin F (1993) Characterization of the glutamate transporter in retinal cones of the tiger salamander. J Neurosci 13:402411.

Fonnum F (1984) Glutamate: a neurotransmitter in mammalian brain. J Neurochem 42:1-11.

Heumann R, Korsching S, Bandtlow C, Thonen H (1987a) Changes of nerve growth factor synthesis in nonneuronal cells in response to sciatic nerve transection. J Cell Biol 104:1623-1631.

Heumann R, Lindholm D, Meyer M, Radeke M, MIsko T, Shooter E, Thoenen H (1987b) Differential regulation of mRNA encoding nerve growth factor and its receptor in rat sciatic nerve during development, degeneration, and regeneration: role of macrophage. Proc Natl Acad Sci USA 84:8735-8739.

Ikeda M, Nakazawa T, Abe K, Kaneko T, Yamatsu K (1989) Extracellular accumulation of glutamate in the hippocampus induced by ischemia is not calcium dependent - in vitro and in vivo evidence. Neurosceience Lett 96:202-206.

Kanai Y, Hediger A (1992) Primary structure and functional characterization of a high-affinity glutamate transporter. Nature 360:467471.

Kanai $\mathrm{Y}$, Stelzner M, Nussherger S, Khawaja S, Hebert SC, Smith CP, Hediger MA (1994) The neuronal and epithelial human high affinity glutamate transporter. Insights into structure and mechanism of transport. J Biol Chem 269:20599-606.

Kanner BI (1993) Glutamate transporters from brain. FEBS Lett 325: 95-99.

Kiryu S, Morita N, Ohno K, Maeno H, Kiyama H (1995) Regulation of mRNA expression involved in Ras and PKA signal pathways during rat hypoglossal nerve regeneration. Mol Brain Res 29:147-156.

Kobayashi NR, Bedard AM, Tetzlaff W (1993) Increased expression of trkB and BDNF mRNA in rat facial motoneurons after axotomy. Soc Neurosci Abstr 19:110.10.

Kobayashi N, Kiyama H, Tohyama M (1994) GAP-43 (B50/F1) gene regulation by axonal injury of the hypoglossal nerve in the adult rat. Mol Brain Res 21:9-18.

Liang P, Pardee AB (1992) Differential display of eukaryotic messenger RNA by means of the polymerase chain reaction. Science 257 : 967.

Liang P, Averboukh L, Keyomarsi K, Sager R, Pardee AB (1992) Differential display and cloning of messenger RNAs from human breast cancer versus mammary epithelial cells. Cancer Res 52:6966-6968.

Lysko PG, Webb CL, Feuerstein G (1994a) Neuroprotective effects of carvedilol, a new antihypertensive, as a $\mathrm{Na}^{+}$channel modulator and glutamate transport inhibitor. Neurosci Lett 171:77-80.

Lysko PG, Webb CL, Yue T-L, Gu J-L, Feuerstein G (1994b) Neuroprotective effects of tetrodotoxin as a $\mathrm{Na}^{+}$channel modulator and glutamate release inhibitor in cultured rat cerebellar neurons and gerbil global brain ischemia. Stroke 25:2476-2482.

McBean GJ, Roberts PJ (1985) Neurotoxicity of L-glutamate and DLthreo-3-hydroxyaspartate in the rat striatum. J Neurochem 44:247254 .

Meister B, Arvidsson U, Zhang X, Jacobsson G, Villar MJ, Hökfelt T (1993) Glutamate transporter mRNA and glutamate-like immunoreactivity in spinal motoneurones. Neuroreport 5:337-340.

Morita N, Namikawa K, Kiyama H (1995) Up-regulation of PKA RI $\alpha$ subunit mRNA in rat skeltal muscle after nerve injury. Neuroreport 6:1050-1052

Nicholls D, Attwell D (1990) The release and uptake of excitatory amino acids. Trends Pharmacol Sci 11:462-468.

Nilsson P, Hillered L, Ponten U, Ungerstedt U (1990) Changes in cor tical extracellular levels of energy-related metabolites and amino acids following concussive brain injury in rat. J Cereb Blood Flow Melab 10:631-637.

Nilsson P, Ronne-Engstrom E, Flink R, Ungerstedt U, Carlson H, Hill- 
ered L (1994) Epileptic seizure activity in the acute phase following cortical impact trauma in rat. Brain Res 637:227-232.

Nishio Y, Aiello LP, King GL (1994) Glucose induced genes in bovine aortic smooth muscle cells identified by mRNA differential display. FASEB J 8:103-106.

Ohno K, Kitahara T, Takeda N, Kubo T, Kiyama H (1994) Gene regulation of cAMP-dependent protein kinase subunits $(\mathrm{C} \alpha, \beta$ : RI $\alpha, \beta$ and $\mathrm{RII} \alpha, \beta)$ in the rat facial motoneurons after nerve transection. Neuroscience 63:1101-1109.

Pines G, Danbolt N, Bjørås M, Zhang Y, Bendahan A, Eide L, Koepsell H, Stormmathisen J, Seeberg E, Kanner BI (1992) Cloning and expression of a rat brain L-glutamate transporter. Nature 360:464-467.

Rothstein JD, Martin LJ, Kuncl RW (1992) Decreased glutamate transport by the brain and spinal cord in amyotrophic lateral sclerosis. $\mathrm{N}$ Engl J Med 326:1464-1468.

Rothstein JD, Martin L, Levey AI, Dykes-Hoberg M, Jin L, Wu D, Nash N, Kuncl RW (1994) Localization of neuronal and glial glutamate transporters. Neuron 13:713-725

Saika T, Senba E, Noguchi K, Sato M, Kubo T, Matsunaga T, Tohyama M (1991) Changes in expression of peptides in rat facial motoneurons after facial nerve crushing and resection. Mol Brain Res 11: 187-196.

Saika T, Kiyama H, Matsunaga T, Tohyama M (1994) Differential reg- ulation of phospholipase $\mathrm{C}$ isozymes in the rat facial nucleus following axotomy. Neuroscience 59:121-129.

Silverstein FS, Buchanan K, Johnston MV (1986) Perinatal hypoxiaischemia disrupts striatal high-affinity $\left[{ }^{3} \mathrm{H}\right]$ glutamate uptake into synaptosomes. J Neurochem 47:1614-1619.

Storck T, Schulte S, Hofmann K, Stoffel W (1992) Structure, expression, and functional analysis of a $\mathrm{Na}^{+}$-dependent glutamate/asparatate transporter from rat brain. Proc Natl Acad Sci USA 89:10955-10959.

Szatkowski M, Barbour B, Attwell D (1990) Non-vesicular release of glutamate from glial cells by reversed electrogenic glutamate uptake. Nature 348:443-446.

Takata M (1993) Two types of imhibitory postsynaptic potentials in the hypoglossal motoneurons. Prog Neurobiol 40:385-411.

Tetzlaff W, Alexander SW, Miller FD, Bisby MA (1991) Response of facial and rubrospinal neurons to axotomy: changes in mRNA expression for cytoskeltal protein and GAP-43. J Neurosci 11:25282544.

Tsui BJ, Cassar SL, Tetzlaff W (1991) Changing in mRNA levels for GAP-43, tubulin and neurofilament-M in rat spinal motoneurons after proximal versus distal axotomy. Soc Neurosci Abstr 17:24.6.

Waxman S, Ransom BR, Stys PK (1991) Non-synaptic mechanisms of $\mathrm{Ca}^{2+}$-mediated injury in CNS white matter. Trends Neurosci 14:461468. 